\title{
COMMENTS
}

\section{EMPLOYER WITHDRAWAL FROM MULTI-EMPLOYER BARGAINING UNITS: A PROPOSAL FOR SELF-REGULATION}

Multi-employer bargaining typically occurs when several employers in one industry join an association to negotiate with a single union. ${ }^{1}$ Small employers in highly competitive businesses are usually eager to bargain through an association because it enables them to present a united front against a union which would otherwise have considerable power to coerce individual employers. ${ }^{2}$ Many unions favor bargaining with an employer association both because it enhances union security ${ }^{3}$ and because multi-employer bargaining assures uniform wages and working conditions throughout the bargaining unit. 4 If both the employer and the union consent to

1 Multi-employer bargaining accounts for $42 \%$ of the major (1,000 employees or more) collective bargaining agreements in this country, and covers over $3,000,000$ workers. Bureau of Labor Statistics, U.S. Dep'T of Labor, Characterustics of Major Coluective Bargatnang Agreements 12 table 1.8 (Bulletin No. 2065, April 1980). These agreements exhibit great variety in the business of employers, the geographical area, and the extent of the industry included. N. CaAmbenuanN \& J. KuHN, Collective Barganning 229-31 (2d ed. 1965) [hereinafter cited as Colr.ective Bargaining].

The classic definition of multi-employer bargaining is found in Rains, Legal Aspects and Problems of Multi-Employer Bargaining, 34 B.U.L. Rev. 159 (1954):

[t]he term multiple employer bargaining refers to all situations in which two or more independent employers bargain or negotiate jointly, through an agent, committee or association, with one or more labor organizations representing employees of the several employers, with respect to wages, hours and other terms and conditions of employment.

Id. 160 .

A multi-employer unit should be distinguished from a multi-plant unit, where one employer bargains with a union or unions representing workers employed in various locations.

2 See Somers, Pressures on an Employers" Association in Collective Bargaining, 6 Indus. \& LAB. ReL. REv. 557, 568 (1963) ("When production is small-scale, competition intense, and employer interests relatively homogenous, association-wide bargaining can provide the benefits of stabilization through wage uniformity and of an increase in bargaining power relative to the union."); see also infra notes 19-29 and accompanying text.

3 The union's security is increased because in order to replace an incumbent, a rival union must win one half of the employees in the entire unit. In individual bargaining, a union can be decertified by a majority vote of workers at a particular plant. See infra notes 33-35 and accompanying text.

4 Standardization of wages helps prevent the discontent that arises when some employees earn more wages than do others in the industry for the same work. See Comment, The Status of Multiemployer Bargaining Under the National Labor Relations Act, 1967 DukE L.J. 558, 560-61. See generally Somers, supra note 2. 
multi-employer bargaining, ${ }^{5}$ the National Labor Relations Board (NLRB or Board) certifies a multi-employer bargaining unit on the theory that such arrangements promote industrial stability. ${ }^{6}$

This Comment focuses on employer withdrawal from multiemployer units. The current Board rule effectively permits an employer to withdraw at any time before bargaining begins, and at no time thereafter. This rule is both too lenient and too strict. It is too lenient because it allows individuals employers to withdraw from the unit for any reason before bargaining begins. ${ }^{7}$ The Board's rule is also too lenient because it permits individual employers to make interim agreements with the union, posing a threat to bargaining unit stability. ${ }^{8}$ An interim agreement is a tentative contract offered by the union to a struck employer, containing a provision requiring the employer to accept whatever terms the union and the multi-employer unit ultimately agree upon. ${ }^{9}$ By signing an interim agreement, a struck employer can return to work, luring customers from its former comrades. The union benefits not only because the association's bargaining position is weakened, but also because union members who return to work after an interim agreement is signed contribute to the strike fund that supports members striking other employers. In spite of these benefits to the union and the settling employer, nonsettling employers are not permitted to withdraw from the multi-employer unit after their association colleagues sign interim agreements.

Finally, the rule is too strict because once contract negotiations begin, an individual employer may withdraw only if it obtains consent of the union, or under narrowly defined "unusual circumstances." 10 In short, the Board's rule does not allow the union to

5 See NLRB v. Sheridan Creations, Inc., 357 F.2d 245, 248 (2d Cir. 1966) ("Multi-employer bargaining is based on the consent of the parties to treat with one another through the agreed units."), cert. denied, 385 U.S. 1005 (1967); see also Electric Theatre, Inc., 156 N.L.R.B. 1351, 1352 (1966) (establishment of a multi-employer unit requires "a controlling history of collective bargaining on such basis, or an unequivocal agreement of the parties to bind themselves to a course of group bargaining in the future."); Collectrve Barganning, supra note 1 , at 243 ("If two parties agree upon a unit, the Board usually confirms it. . .").

${ }^{6}$ See NLRB v. Truck Drivers Local 449, 353 U.S. 87 (1957); StafF of GEN. SUBCOMM. ON LABOR OF THE HoUSE COMM. ON Education aNd LABOR, 88Th Cong., 2D SEss., Multtemployer Bargatning and tTs Impact on the Collectrve Bargaindng Process 32 (Comm. Print 1964) [hereinafter cited as Comamtroe Print].

7 Retail Assocs., 120 N.L.R.B. 388, 395 (1958).

8 Sangamo Construction Co., 188 N.L.R.B. 159 (1971).

$9 I d .160$.

10 Retail Assocs., 120 N.L.R.B. at 395. For a general discussion of the Board's withdrawal rule, see Comment, Withdrawal from Multi-Employer Bargaining-Reconsidering Retail Associates, 115 U. PA. L. REv. 464 (1967). 
formulate reasonable expectations about the size or stability of the unit before negotiations begin. Nor does it allow employers to escape from the unit after negotiations begin, regardless of developments in the employer's business or in the bargaining process.

In response to these weaknesses in the Board's rule, and its perceived pro-union bias, four circuit courts fashioned a doctrine permitting employer withdrawal whenever an impasse in bargaining occurred.11 The courts reasoned that impasse, like fragmentation of the unit or severe employer economic distress, ${ }^{12}$ was an "unusual circumstance." The Board consistently opposed the impasse doctrine, ${ }^{13}$ and the doctrine was criticized because of the difficulty of defining when impasse occurs and the impasse standard's susceptability to manipulation by both unions and employers. ${ }^{14}$

The Supreme Court recently rejected the impasse doctrine in Charles D. Bonanno Linen Service, Inc. v. NLRB.15 The Court refused to consider the appropriate balance of employer and union interests, reasoning that it must defer to the Board's balancing of "conflicting legitimate interests." 10 Responding to the assertion that the Board's current rule favored union interests over employer interests, the Court declared that "the Board . . . has developed a rule which, although it may deny an employer a particular economic weapon, does so in the interest of the proper and pre-eminent goal, maintaining the stability of the multi-employer unit." 17

This Comment agrees with the rejection of the impasse doctrine. It suggests, however, that the Bonanno Court did not go far enough; because employers need different types of associations, no public rule can possibly accommodate the diverse interests and policies involved in regulating withdrawal.

Employers who believe that they benefit from individual bargaining seek a loosely structured association, and would be ham-

$11 \mathrm{H} \& \mathrm{D}$, Inc. v. NLRB, 633 F.2d 139 (9th Cir. 1980), vacated, 50 U.S.L.W. 3570 (U.S. Jan. 18, 1982); NLRB v. Independent Ass'n of Steel Fabricators, 582 F.2d 135 (2d Cir. 1978), cert. denied, 439 U.S. 1130 (1979); NLRB v. Beck Engraving Co,, 522 F.2d 475 (3d Cir. 1975); NLRB v. Hi-Way Billboards, Inc., 500 F.2d 181 (5th Cir. 1974). But see infra note 67 (two circuits recently abandoned impasse doctrine; three circuits retain it).

12 See infra notes 59-60.

13 Hi-Way Billboards, Inc., 206 N.L.R.B. 22 (1973), enforcement denied, 500 F.2d 181 (5th Cir. 1974).

14 See Murphy, Impasse and the Duty to Bargain in Good Faith, 39 U. Prrr. L. REv. 1 (1977); Recent Developments, 44 ForDHAM L. Rev. 1256 (1976). But see Annual Survey of Labor Law-Withdrawal of Multi-Employer Units Upon Impasse: Independent Ass'n of Steel Fabricators, 21 B.C.L. REv. 85, 126 (1979). 1550 U.S.L.W. 4087 (U.S. Jan. 12, 1982), aff'g 630 F.2d 25 (1st Cir. 1980). 1650 U.S.L.W. at 4091.

17 Id. 
pered by a rule severely limiting withdrawal. Employers who seek security and certainty desire a static and cohesive bargaining group, and their expectations would be frustrated by a liberal withdrawal rule. Therefore, this Comment proposes private ordering as an alternative to an administratively or judicially established withdrawal rule.

In a private regulation scheme, associations would design their own written agreement governing all aspects of members' behavior, including withdrawal. If the contract provisions were not contrary to public policy, and the union agreed to bargain with the association, the NLRB would certify the unit. The association would thus become an "employer," and withdrawal contrary to the terms of the agreement would be an unfair labor practice. ${ }^{18}$

Part I of this Comment explains why employers and unions agree to engage in multi-employer bargaining, and why they might wish to withdraw from a multi-employer unit. Part II examines the Board's rule on withdrawal and the impasse doctrine, explaining why both are theoretically and practically inadequate. Part III proposes self-regulation as a solution, and discusses the implementation of such a system.

\section{The Advantages of Multi-Employer Bargaining}

\section{A. The Advantages to Employers}

Employers bargaining through an association enjoy three advantages unavailable to employers bargaining individually. The foremost advantage is size, for labor negotiations are no exception to the rule that "there is strength in numbers." Small employers facing strong national unions are typically in a weak bargaining position. ${ }^{19}$ The union can force them to succumb to its demands by threatening a strike. Smaller employers usually lack the economic resources to withstand a long work stoppage, and know the crippling effect of strikes in terms of business lost to competitors.

18 Withdrawal in defiance of a self-regulation agreement would be a violation of $\$ 8(\mathrm{~b})(3)$ of the National Labor Relations Act (NLRA), 29 U.S.C. $\$ 158(\mathrm{~b})(3)$ (1976), forbidding refusal to bargain collectively with the representative of the employer. See infra notes $98-100$ and accompanying text; cf. Teamsters Local 378, 243 N.L.R.B. 1086, 1089 (1979) (unfair labor practice for union to negotiate separate settlement without the multi-employer association's consent), application for enforcement pending, No. 79-7683 (9th Cir. argued Nov. 5, 1980).

$19 \mathrm{~S}$. Garpett \& L. Trup, Management Problems Implitct in Mulitemployer Bargatning 3 (1949); C. Kerr \& R. Randati, Collective Bargatning in the Pacific Coast Pulp and Paper Industry 2-4 (1948); Comment, supta note 4 , at 559 . 
Multi-employer bargaining allows these employers to improve their bargaining posture by presenting a united front against the union. ${ }^{20}$ Increased size increases the employers' bargaining leverage, because the union cannot be sure that it will prevail in a strike, and because employers need not fear losing business to competitors, who are also being struck. ${ }^{21}$ The economies of scale accompanying increased size also benefit employers by allowing them-through the association-to design a more sophisticated bargaining strategy ${ }^{22}$ and to provide employees with more benefits. ${ }^{23}$

Besides economic advantages, employers benefit from group bargaining because it permits the use of lockouts to counteract whipsaw strikes. ${ }^{24}$ In a whipsaw strike, the union strikes employers one by one, waiting until each employer capitulates before striking the next. ${ }^{25}$ In NLRB v. Truck Drivers Local $449,{ }^{26}$ the Supreme Court held that all association members in a multi-employer unit could lock their employees out of the workplace, effectively nullifying the whipsaw strike. ${ }^{27}$ Although single employers may lock employees out for a legitimate business reason, ${ }^{28}$ multi-employer associations are unique because employers may lock their employees out solely to support a struck fellow employer. ${ }^{29}$

20 See NLRB v. Truck Drivers Local 449, 353 U.S. 87, 94-95 (1957) (multiemployer bargaining "has had its greatest expansion since enactment of the Wagner Act because employers have sought through group bargaining to match increased union strength").

21 See generally Commrtes PRnN, supra note 6, at 1-19.

22 For example, employers can pool their resources and hire a skilled negotiator. Comment, supra note 4 , at 561 .

23 These benefits include, for example, pension plans, medical benefits, unemployment compensation and industry-wide apprenticeship and training programs. See Comment, supra note 4, at 561; Herold, Multiemployer Bargaining and the Whipsaw Strike: The Use of a Lockout as an Economic Weapon, 21 BrookLyN BARRISTER 54, 54-55 (1969).

24 See Brundage, The Lockout and Multi-Employer Bargaining, 14 LAB. L.J. 976, 977 (1963); Comment, supra note 4, at 559-60; see also Recent Developments, supra note 14, at 1257 (concluding that preventing whipsaw strikes is the most significant protection gained by an employer in multi-employer bargaining).

25 The union benefits from the struck employer's fear of losing customers to local competitors. Herold, supra note 23, at 54. Striking employees may benefit from a strike fund contributed to by locals whose members continue to work and by employees of employers who have capitulated to the whipsaw strike. Id.

26353 U.S. 87 (1957).

27 Id. 97. The Court noted that multi-employer bargaining was crucial to the "effectuation of the national policy of promoting labor peace through strengthened collective bargaining." Id. 95 .

28 American Ship Building Co. v. NLRB, 380 U.S. 300 (1965).

29 Truck Drivers, 383 U.S. at 79. Employers may also prefer multi-employer bargaining because it circumvents "irresponsible" local unions. The employers 


\section{B. Advantage for Unions}

Besides requiring agreement from individual employers, certification of a multi-employer bargaining unit requires union consent. A union will only agree to bargain in this fashion when the cost of increased employer strength is outweighed by union benefits. Union advantages involving economies of scale, as with increased welfare benefits ${ }^{30}$ and more efficient bargaining, ${ }^{31}$ are comparable to employers' advantages. Unions also secure guaranteed uniformity of wages and working conditions throughout the unit, rather than being forced to negotiate with each employer separately over such terms. ${ }^{32}$

The most important advantage for unions is enhanced security. Once certified by the Board, a union representing a multi-employer unit is, in practice, almost impossible to supplant. Even for another union to call for a decertification election requires the formidable task of securing the signatures of thirty percent of the employees across the entire bargaining unit. ${ }^{33}$ Decertification requires a majority vote of employees in the unit. ${ }^{34}$ Thus, even if every employee in a plant votes against the incumbent union, it will continue to represent the employees unless more than half of the total number of employees in the unit vote for decertification. ${ }^{35}$

bargaining with the national union may seek to persuade it to eliminate rules that are troublesome to the employers at the local level. Colnectrve Bargannang, supra note 1, at 252-53. But see NLRB v. Miller Brewing Co., 408 F.2d 12 (9th Cir. 1969) (requiring employer member of an association to bargain on local matters with local union.).

30 See supra note 23.

31 The union's greatest efficiency is negotiation of a single contract instead of a series of contracts. It has also been suggested that multi-employer bargaining may involve high-level company policy makers, giving the umion greater access to those who make controlling decisions. Coltectrve BARGatnING, supra note 1, at 253-54.

32 J. Abodeely, R. Hammer \& A. SANDler, The NLRB and the Approprrate BARGAINING UNIT 218-19 (rev. ed. 1981) [hereinafter cited as APpRopriate Bargatning Unit]; R. Gorman, Bastc Text on Labor Law 87 (1976). Wages and payments to insure safe working conditions often represent a significant part of the cost of the final product. But if unions or employers attempt to skimp on these items, there may be severe repercussions in the work force. See G. Broom \& H. Northrud, Economics of Labor Relations 211-14 (8th ed. 1977); Colrective BargannING, supra note 1 , at 247. See generally T. KENNEDX, ThE Significance OF WAGE UNIFORMTTY (1949).

33 NLRA, $\$ 9(e)(1), 29$ U.S.C. $\$ 159(e)(1)$ (1976).

$34 I d$.

35 Joseph J. Callier, 243 N.L.R.B. 1114 (1979), enforced, 630 F.2d 595 (8th Cir. 1980); Sheridan Creations, Inc., 148 N.L.R.B. 1503 (1964), enforced, 357 F.2d 245 (2d Cir. 1966), cert. denied, 385 U.S. 1005 (1967).

Of course, the process can also work against the incumbent: a rival union can take over a unit if it wins the majority of votes across the unit, even if it does not 


\section{The Pressures to Withdraw}

After voluntarily entering into an association, an employer may be persuaded by changing conditions that a return to individual bargaining would prove beneficial. ${ }^{36}$ Unexpected economic developments may prompt the change of heart. ${ }^{37}$ Or, an employer may discover that its views on bargaining strategy differ radically from those of other association members and that it has insufficient power within the organization to implement those views.

The withdrawal of other association members may also provide the motivation for employer withdrawal. ${ }^{38}$ In these cases, the ultimate composition of the unit fails to conform to the employer's original expectations. Permanent withdrawal by important members of the association may reduce the group's bargaining leverage making the independence available to an employer in individual bargaining more desirable.

Temporary withdrawal, precipitated by individual interim agreements between association members and the union, may also lead nonsettling employers to seek to withdraw. Association members signing interim agreements are bound to the final association contract, and are thus still members of the association. ${ }^{39}$ Their temporary withdrawal, however, may reduce the association's effecaiveness even more than permanent withdrawals because interim

gain majority support in every plant. This occurred in the pulp and paper industry in 1964, as the Western Pulp and Paper Workers ousted the AFL-CIO after 30 years of representation. G. Bloom \& H. NorTHRup, supra note 32, at 214.

The advantages gained by unions and employers from multi-employer bargaining are not produced cost-free. Employees and consumers bear special costs from the arrangement. Employees find that enhanced union security reduces their free choice in selecting bargaining representatives. A union may join a multi-employer unit without consulting the employees. Although the employees might have opposed the decision, favoring local autonomy, their only chance to defeat the union would be at a unit-wide election.

Consumers may find that multi-employer bargaining increases the price that they pay for goods and services produced by that industry. Competing producers bargaining together can easily pass on increased wages directly to consumers. They risk, however, being undersold by competitors who do not belong to the association, or by producers of competing goods.

30 "The boundary lines of bargaining units are not fixed and unchanging, but variable, the parties in collective bargaining adjusting them to fit their needs." Collective Bargatning, supta note 1, at 263.

37 For example, the demand for a certain product may decrease dramatically, changing the size and type of bargaining units. See id. 248-52.

38 As members leave an association, its bargaining strength declines. The employer may then become more concerned with getting out of the weakened association than with bargaining. See S. GarRerT \& L. Tripp, supra note 19, at 60 .

39 See NLRB v. Charles D. Bonanno Linen Serv. Inc., 630 F.2d 25, 30 (1st Cir. 1980), aff 50 U.S.L.W. 4087 (U.S. Jan. 12, 1982). 
agreements are usually reached at a critical juncture in bargaining, or during a strike. ${ }^{40}$ With an interim agreement, the settling employer remains in operation, taking customers from struck members, and destroying the expectations of mutual support which inspired formation of the unit. ${ }^{41}$

\section{The Current Law}

\section{A. The Board's Rules for Multi-employer Bargaining}

\section{Certification of Multi-employer Units}

Since its inception, the NLRB has assumed the power to certify multi-employer bargaining units, ${ }^{42}$ and its authority to do so has withstood challenges in Congress ${ }^{43}$ and before the Supreme Court. ${ }^{44}$

40 See, e.g., Teamsters Local 378, 243 N.L.R.B. 1086, 1088-89 (1979), application for enforcement pending, No. 79-7683 (9th Cir. argued Nov. 5, 1980); Plumbers \& Steamfitters Union 323, 191 N.L.R.B. 592 (1971); Sangamo Construction Co., 188 N.L.R.B. 159 (1971).

41 See Recent Developments, supra note 14, at 1262:

The individual employer who agrees to a separate contract or "interim agreement" weakens the strength of the association. In addition, as [its] employees return to work, pressure is brought to bear on the remaining employers to accede to the union's demands or face competitive disadvantage. The resulting whipsaw effect on the multiemployer association leaves it with considerably less bargaining power.

42 The NRLA never mentions multi-employer bargaining, despite the fact that bargaining on that basis took place before the Wagner Act was enacted. See NLRB v. Truck Drivers Local 449, 353 U.S. 87, 94-95 (1957). The Board derived its power to approve such units in Shipowners' Ass'n, 7 N.L.R.B. 1002 (1938), appeal dismissed sub nom. AFL v. NLRB, 103 F.2d 933 (D.C. Cir. 1939), aff'd, 308 U.S. 401 (1940), reasoning from $\$ 9(\mathrm{~b})$ of the NLRA. That section states: "The Board shall decide in each case whether, in order to assure to employees the fullest freedom in exercising the rights guaranteed by this Act, the unit appropriate for the purposes of collective bargaining shall be the employer unit, craft unit, plant unit, or subdivision thereof." 29 U.S.C. $\$ 159$ (b) (1976). The Board held that because "employer" includes "any person acting as an agent of an employer," 29 U.S.C. $\$ 152(2)$ (1976), and "person" includes "associations," 29 U.S.C. \$152(1) (1976), it could designate an association as the statutory representative of the employers. See Shipowners' Ass'n, 7 N.L.R.B. at 1024-25.

43 When Congress was considering the Labor Management Relations (TaftHartley) Act, Pub. L. No. 79-101, 61 Stat. 136 (1947) (codified in scattered sections of 29 U.S.C.), multi-employer bargaining was a hotly debated issue. The Senate tried to authorize the Board to certify industry-wide units entered voluntarily by employers. S. REP. No. 105, 80th Cong., Ist Sess. 6-8 (1947). The House Committee opposed multi-employer bargaining, and attempted to impose severe limitations upon the Board's power to authorize it. H.R. REP. No. 245, 80th Cong., 1st Sess. 552-53 (1947). Neither provision was passed, so legislative intent about the scope of multi-employer bargaining is unclear.

44 In NLRB v. Truck Drivers Local 449, 353 U.S. 87 (1957), the Supreme Court interpreted the legislative silence on the issue as an endorsement of the Board's policy. Id. 95-96. 
Because national labor policy presumptively favors individual bargaining, ${ }^{45}$ the Board will certify multi-employer units only if both the association members and the union manifest "an unequivocal intention to be bound in collective bargaining by group rather than individual action." 46

The Board requires that this manifestation of intention be "something less ... than a solemnly executed document signed and sealed with hot wax. . . . An employer who, through a course of conduct or otherwise, signifies that it has authorized the group to act in its behalf will be bound by that apparent creation of authority." 47 Thus, the Board looks primarily to the parties' bargaining history in deciding whether to certify a multi-employer unit. 48

If the parties have bargained jointly, and abided by the results of negotiations in the past, a multi-employer unit will probably be certified. $^{49}$ In some situations, however, the union or particular employers may no longer want to bargain on a multi-employer basis. Nevertheless, if the Board decides that bargaining history controls, the parties may be bound to the unit despite their contrary preference. ${ }^{50}$

Employers who negotiate together informally may discover, despite the absence of an association, that they are members of a multi-employer unit. ${ }^{.1}$ Thus, if certain policies are worked out as a

45 Cab Operating Corp., 153 N.L.R.B. 878, 879 (1965); Carbondale Retail Druggists' Ass'n, 131 N.L.R.B. 1021, 1022 (1961); John Breuner Co., 129 N.L.R.B. 394, 396 (1960).

46 Joseph McDaniel, 226 N.L.R.B. 851, 852 (1976) (footnote omitted), enforced sub nom. NLRB v. Beckham, Inc., 564 F.2d 190 (5th Cir. 1977); see Bill O'Grady Carpet Serv., Inc., 185 N.L.R.B. 587 (1970); Korner Kafe, Inc., 156 N.L.R.B. 1157 (1966); Fairbanks Dairy, 146 N.L.R.B. 893 (1964).

47 Joseph McDaniel, 226 N.L.R.B. at 853 (footnote omitted).

48 E.g., Electric Theatre, Inc., 156 N.L.R.B. 1351 (1966); Jahn-Tyler Printing \& Publishing Co., 112 N.L.R.B. 167 (1955).

40 "When employers have built up a controlling history of bargaining with their employees on a multiemployer basis, the Board will almost always certify such a unit as appropriate." Continental Baking Co., 99 N.L.R.B. 777 (1952).

50 See, e.g., Shreveport-Bossier Cleaners \& Laundries, Inc., 124 N.L.R.B. 534 (1959); Stouffer Corp., 101 N.L.R.B. 1331 (1952); Crucible Steel Castings Co., 90 N.L.R.B. 1843 (1950); Waterfront Employers Ass'n, 71 N.L.R.B. 80 (1946). See generally Collective BargatnING, supra note 1, at 243, 244 \& n.11. Because of this prior bargaining history rule, the consensual nature of multi-employer bargaining has been questioned. See Commrrtee Prant, supra note 6, at 21; Comment, Multiemployer Bargaining and the National Labor Relations Board, 66 Harv. L. REv. 886, 889 (1953); Comment, supra note 4, at 564, 570.

61 Joseph McDaniel, 226 N.L.R.B. 851 (1976), enforced sub nom. NLRB v. Beckham, Inc., 564 F.2d 190 (5th Cir. 1977). 
group, but each employer signs a separate contract with the union, ${ }^{52}$ the Board may rule that the employers are part of a multi-employer unit. $^{\text {s3 }}$

\section{The Board's Withdrawal Rule}

Because the right to withdraw from multi-employer units at will would destroy the stability of bargaining and with it industrial peace, the Board established a rule governing withdrawal in Retail Associates. ${ }^{54}$ Either individual employers or the union may withdraw at any time before contract negotiations commence, provided that adequate notice is given. Once negotiations begin, however, employer withdrawal is permitted only with the consent of the union, or under "unusual circumstances." ${ }^{55}$ The Board has limited these unusual circumstances to severe economic distress, ${ }^{56}$ or severe fragmentation of the bargaining unit. ${ }^{57}$ Despite pressure from circuit courts, the NLRB has refused to interpret unusual circum-

52 See, e.g., Checker Cab Co., 141 N.L.R.B. 583, 587 (1963), enforced, 367 F.2d 692 (6th Cir. 1966), cert. denied, 385 U.S. 1008 (1967).

53 In Checker, the cab employers' membership corporation contended that each employer should bargain with the union separately. The union sought to represent all employees who drove Checker cabs for any employer. The Board held for the union, reasoning that:

Checker and its members contend that separate units of each members employee drivers are appropriate. However, as we have stated above, Checker and its members seek to establish and preserve the public image and the operating reality and benefit of a single integrated enterprise. Pursuant thereto, all the drivers have similar working conditions and mutual employment interests. In addition, no union seeks to represent the drivers on any other basis. In view of the above, and in view of our finding of a joint employer relationship between Checker and each of its members in one common enterprise under the aegis of Checker, we find a unit of all employees driving Checker cabs to be appropriate.

141 N.L.R.B. at 587.

Thus, despite the absence of bargaining history or employer consent, the Board found a multi-employer unit appropriate. This decision implies that an employer must avoid collaboration with fellow employers on any issue, whether or not related to negotiations with the union, in order to avoid being bound to a multi-employer unit. See also McAx Sign Co., 231 N.L.R.B. 957 (1977), enforced, 576 F.2d 62 (5th Cir. 1978) (employer did not formally authorize group bargaining, but Board and court found that it manifested the intention to bargain through an association based on prior bargaining history and course of conduct in disputed negotiations), cert. denied, 439 U.S. 1116 (1979); Quality Limestone Products, Inc., 143 N.L.R.B. 589 (1963); Waterfront Employers Ass'n, 71 N.L.R.B. 80 (1946).

54120 N.L.R.B. 388 (1958).

55 Id. 395.

${ }^{56}$ See, e.g., Atlas Electrical Serv. Co., 176 N.L.R.B. 827, 830 (1969); Spun-Jee Corp., 171 N.L.R.B. 557, 558 (1968); United States Lingerie-Corp., 170 N.L.R.B. 750,751 (1968).

67 See, e.g., Typographic Serv. Co., 238 N.L.R.B. 1565, 1566 (1978); Connell Typesetting Co., 212 N.L.R.B. 918, 921 (1974). 
stances to include an impasse in bargaining ${ }^{58}$ or an individual employer's signing an interim agreement. ${ }^{59}$

\section{The Problems with the Board's Rules}

The Board's rules governing multi-employer bargaining units are compromises between the competing goals of flexibility and stability. Of at least equal importance, however, is the need for certainty. The Board's rules do not provide guidelines clear enough to tell an employer when it is likely to be bound to a multi-employer unit and when it is not. The resulting uncertainty prevents employers from making an informed choice whether to engage in multi-employer bargaining.

The Board's certification rule creates uncertainty both for employers who wish to bargain through an association and for those who prefer to bargain individually. Employers attempting to form an association cannot be sure what history of joint bargaining or of cooperation is necessary to ensure certification as a multi-employer unit. In contrast, employers who wish to bargain together informally, or on limited subjects, must be wary of the Board's misinterpreting their intentions and ordering multi-employer bargaining.

The Board's withdrawal rule, however, is the major source of confusion. The ease of withdrawal before negotiations begin may frustrate the employer who felt assured of the security of a stable, cohesive bargaining group, only to find other employers seeking

68 Golden Bear Motors, Inc., 245 N.L.R.B. 300 (1979); Florida Fire Sprinklers, Inc., 237 N.L.R.B. 1034 (1978); Bill Cook Buick, Inc., 224 N.L.R.B. 1094 (1976); Hi-Way Billboards, Inc., 206 N.L.R.B. 22 (1973), enforcement denied, 500 F.2d 181 (5th Cir. 1974).

69 The rationale for holding that signing interim agreements does not constitute an unusual circumstance is that such agreements do not disrupt employers' legitimate expectations about bargaining unit structure. Charles D. Bonanno Linen Service, Inc., 243 N.L.R.B. 1093 (1979), enforced, 630 F.2d 25 (Ist Cir. 1980), aff'd, 50 U.S.L.W. 4087 (U.S. Jan. 12, 1928); Hi-Way Billboards, Inc., 206 N.L.R.B. 22 (1973), enforcement denied, 500 F.2d 181 (5th Cir. 1974).

In addition to holding that impasse and interim agreements are not unusual circumstances, the Board has ruled that none of the following meet that standard: an employer's good faith doubts about a union's majority status, Sheridan Creations, Inc., 148 N.L.R.B. 1503 (1964), enforced, 357 F.2d 245 (2d Cir. 1966), cert. denied, 385 U.S. 1005 (1967); the discharge of all the employer's workers represented by the union, John J. Corbett Press, Inc., 163 N.L.R.B. 154, 156 (1967), enforced, 401 F.2d 673 (2d Cir. 1968); separate permanent agreements between the union and some association members, Tobey Fine Papers, 245 N.L.R.B. 1393, 1395 (1979), enforced, 659 F.2d 841 (8th Cir. 1981); WE Painters, Inc., 176 N.I.R.B. 964, 965-66 (1969), and a sharp decline in the employer's business. Serv-All Co., 199 N.L.R.B. 1131, 1141 (1972), enforcement denied, 491 F.2d 1273 (10th Cir. 1974). 
independence by withdrawing on the eve of bargaining. The limits on withdrawal after negotiations begin present an even more difficult situation, for the employer who wishes to withdraw can never be sure how much economic distress must occur ${ }^{\circ 0}$ or how badly the bargaining unit must be fragmented ${ }^{61}$ before withdrawal can be accomplished without an unfair labor practice charge.

The rules regulating employer withdrawal based on separate agreements with the union have also been a source of uncertainty. Because employers and unions have equal withdrawal rights, ${ }^{62}$ a union may consent to an employer withdrawing at any time. In addition, a union may in some cases negotiate a separate, permanent agreement with one employer-effectively allowing that employer to withdraw from the unit-without endangering multi-employer bargaining. ${ }^{63}$ Finally, the union may negotiate interim settlements with some employers-allowing "temporary withdrawal" from the unit-without permitting other association members to withdraw. ${ }^{\text {it }}$

The Board's rule permits the union to employ the reverse whipsaw, a potent weapon for dismantling the association's bargaining leverage. ${ }^{e s}$ In a reverse whipsaw, the union strikes all association members, and then one by one offers the employers separate

60 See, e.g., Western Pacific Roofing Corp., 244 N.L.R.B. 501 (1979).

61 See Tobey Fine Papers, 245 N.L.R.B. 1393 (1979), enforced on other grounds, 659 F.2d 841 (8th Cir. 1981) (employer not permitted to withdraw although 2 of 14 association members permanently withdrew; those 2 members employed $42 \%$ of the unit's employees); Birkenwald, Inc., 243 N.L.R.B. 1151 (1979) (1 of $11 \mathrm{em}$ ployers in unit signed permanent agreement; withdrawal not permitted although that employer employed $30 \%$ of the unit's employees); Connell Typesetting Co., 212 N.L.R.B. 918 (1974) (withdrawal permitted after 23 of 36 employers, employing 173 of 209 employees, permanently withdrew). The Board stated that it did not consider the degree of bargaining strength to be the determinative factor in fragmentation cases. Charles D. Bonanno Linen Serv., Inc., 243 N.L.R.B. at 1097.

62 Evening News Ass'n, 154 N.L.R.B. 1494 (1965), enforced sub nom. Detroit Newspaper Publishers Ass'n v. NLRB, 372 F.2d 569 (6th Cir. 1967).

63 See, e.g., Tobey Fine Papers, 245 N.L.R.B. 1393, 1395 (1979) ("it does not follow ipso facto that execution of individual separate final contracts with former Association members either proves an intention to destroy, or necessarily causes the fragmentation of, a multiemployer unit."), enforced on other grounds, 659 F.2d 841 (8th Cir. 1981).

64 The Board does not view interim settlements as disruptive of the association. Charles D. Bonanno Linen Serv., Inc., 243 N.L.R.B. 1093 (1979), enforced, 630 F.2d 25 (1st Cir. 1980), aff'd, 50 U.S.L.W. 4087 (U.S. Jan. 12, 1982); Joseph J. Callier, 243 N.L.R.B. 1114 (1979), enforced, 630 F.2d 595 (8th Cir. 1980); Plumbers \& Steamfitters Union 323, 191 N.I.R.B. 592 (1971); Sangamo Constuction Co., 188 N.L.R.B. 159 (1971). The exception to the rule that interim settlements do not permit withdrawal is when the settlements cause severe fragmentation of the bargaining unit. See Connell Typesetting Co., 212 N.L.R.B. 918 (1974).

${ }^{65}$ See NLRB v. Beck Engraving Co., 522 F.2d 475 (3d Cir. 1975). 
interim agreements. As in the whipsaw strike, the employer has more incentives to capitulate than to resist. If it accepts an interim agreement, the employer can return to work without fear of competitive disadvantage; the union will use that agreement as leverage to settle with the other association members on the same terms. If the employer refuses, it chances losing customers to the settling competitors.

The reverse whipsaw gives the union a significant economic weapon, but employers cannot respond by locking out their employees. Nor can they withdraw from the association and undertake individual negotiations with the local. Thus, the union's power to withhold consent and to offer separate agreements permits it to decide which employers will be released from the multi-employer unit, and which will be locked in. ${ }^{60}$

\section{B. The Courts Respond: The Impasse Doctrine}

\section{The Rationale for the Doctrine}

Responding to the perceived unfairness of the Board's withdrawal rule, three circuits held that an impasse in bargaining was an unusual circumstance justifying withdrawal by any employer. ${ }^{67}$ Despite the Board's consistent position that an employer attempting a unilateral withdrawal at impasse committed an unfair labor practice, ${ }^{68}$ the courts reasoned that at impasse the union had "two

66 A further difficulty with current Board rules is the problem of employee rights. Although the employees choose the union on a plant-by-plant basis, the decision to bargain in a multi-employer bargaining unit is made afterwards, without consulting the employees. Thus, employees opposed to group bargaining may nonetheless be forced into the larger unit. See, e.g., Stouffer Corp., 101 N.L.R.B. 1331, 1332 n.3 (1952) (citing Belle Vernon Milk Co., 90 N.L.R.B. 717 (1950)). Because decertification of the union requires majority support across the entire unit, see supra notes 33-35 and accompanying text, employees at one plant may oppose the group bargaining structure without being able to remove themselves from it. See generally Brooks, Stability Versus Employee Choice, 61 CoRnex. L. REv. 344 (1976); Brooks \& Thompson, Multiplant Units: The NLRB's Withdrawal of Free Choice, 20 Indos. \& LAB. Rex. Rev. 363, 378 (1967).

67 NLRB v. Independent Ass'n of Steel Fabricators, 582 F.2d 135 (2d Cir. 1978), cert. denied, 439 U.S. 1130 (1979); NLRB v. Beck Engraving Co., 522 F.2d 475 (3rd Cir. 1975); NLRB v. Associated Shower Door Co., 512 F.2d 230 (9th Cir.), cert. denied, 423 U.S. 893 (1975).

In addition, two other circuits recently abandoned the impasse doctrine. Compare NLRB v. Marine Machine Works, 635 F.2d 522 (5th Cir. 1981) and Tobey Fine Papers v. NLRB, 659 F.2d 841 (8th Cir. 1981) with NLRB v. Hi-Way Billboards, Inc., 500 F.2d 181 (5th Cir. 1974) and Fairmont Foods Co. v. NLRB, 471 F.2d 1170 (8th Cir. 1972).

68 Charles D. Bonanno Linen Serv., Inc., 243 N.L.R.B. 1093 (1979), enforced, 630 F.2d 25 (1st Cir. 1980), affd, 50 U.S.L.W. 4087 (U.S. Jan. 12, 1982); Hi-Way Billboards, Inc., 206 N.L.R.B. 22 (1973), enforcement denied, 500 F.2d 181 (5th Cir. 1974). 
weapons for its economic arsenal (i.e, the selective strike and individual negotiations) while the employers are given only one (viz., the lockout)." ${ }^{69}$ The impasse doctrine, in the court's view, redressed that imbalance.

The primary rationale for the impasse rule was that the union could negotiate interim agreements. In refusing to tie withdrawal rights to the actual negotiation of separate agreements, one court reasoned that such a rule would give the "party whose right accrues first . . . a tremendous bargaining advantage and leverage." 70 Instead, the court linked withdrawal to impasse, "an event which neither [party] can manipulate . . . ." 71 A second court embracing the impasse doctrine based its decision on the view that "the objectives of collective bargaining would be ill-served by compelling employers to remain in the bargaining unit once it becomes clear that no progress is being made within that framework." 72 Both these courts acknowledged that the impasse doctrine could erode the stability of multi-employer units, but concluded that an appropriate balance of the union's and employer's interests required adoption of the rule.

\section{Rejection of the Doctrine}

The Supreme Court recently rejected the impasse doctrine in favor of the Board's rule. In Charles D. Bonanno Linen Service, Inc. $v . N L R B,{ }^{73}$ the Supreme Court rejected the impasse doctrine. In that case, the employer suffered a selective strike, and, although no interim agreements were signed, informed the association that it wished to withdraw from the bargaining unit. The employer refused to sign or be bound by the subsequent contract between the union and the association.

${ }^{69}$ Beck Engraving, 522 F.2d at 483.

$70 \mathrm{Id}$.

71 Id. For a general discussion and criticism of the decision, see Note, Effect of Negotiating Impasse on an Employer's Right to Withdraw From a MultiEmployer Bargaining Association-NLRB v. Beck Engraving Co., 17 B.C. Irdus. \& CoM. L. Rev. 525 (1976).

72 NLRB v. Independent Ass'n of Steel Fabricators, 582 F.2d 135, 146 (2d Cir. 1978), cert. denied, 439 U.S. 1130 (1979). For a discussion of the case, see Comment, From Chains of Iron to Ropes of Sand: Employer Withdrawal From Multiemployer Bargaining After Steel Fabricators, 45 BrookLYN L. REv. 1283 (1979); Annual Survey of Labor Law-Withdrawal of Multi-Employer Units Upon Impasse: Independent Ass'n of Steel Fabricators, 21 B.C.L. REv. 119 (1979).

7350 U.S.L.W. 4087 (U.S. Jan. 12, 1982), aff'g 630 F.2d 25 (1st Cir. 1980). The rejection of the impasse doctrine follows the recent trend in the courts of appeals. See supra note 67. 
The Court concluded that the Board acted within the proper scope of its authority in finding that the employer committed an unfair labor practice by refusing to bargain. The Court noted that impasse was generally a "temporary deadlock ... in negotiations" "t which could be resolved through bargaining, and that the notion of impasse itself was subject to manipulation..$^{75}$

The Court also accepted the Board's position on interim agreements, holding that neither strikes nor interim agreements are necessarily associated with impasse and that a distinction should be made between "truly interim" and "separate final" agreements. In the former case, an employer is bound by the ultimate contract negotiated by the association, while the latter is "inconsistent with the concept of multiemployer bargaining units." "76

\section{An Evaluation of the Doctrine}

The Supreme Court in Bonanno was faced with a choice between two inadequate alternatives. The Board rule clearly favors unions over employers, ${ }^{77}$ prompting Chief Justice Burger in dissent to suggest that the rule "create[d] an artificial and unwarranted imbalance of economic weapons." 78

The Chief Justice disputed the majority's suggestion that the impasse was temporary; he found "a complete breakdown in negotiating coupled with a prolonged strike and lockout." 79 He argued that forcing the parties to remain in that stalemate would be futile, and contended that withdrawal at impasse actually facilitates, rather than frustrates, bargaining. ${ }^{80}$

The Chief Justice also disagreed with the idea that the concept of impasse is too vague to determine withdrawal rights. He argued

7450 U.S.L.W. at 4090.

75 Id. (citing Charles D. Bonanno Linen Serv., Inc., 243 N.L.R.B. at 1093-94).

7850 U.S.L.W. at 4090 . The Court's rationale for permiting interim agreements was that "all employers, including those executing interim agreements, have an 'equivalent stake' in the final outcome because "the resulting group agreement would then apply to all employers, including each signer of an interim agreement." Id. (citing Bonanno, 243 N.I.R.B. at 1096).

The Court also agreed with the Board's decision to balance "conflicting legitimate interests" instead of "economic weapons and bargaining strength." 50 U.S.L.W. at 4091. By contrast, the Chief Justice declined to give "abject deference to the Board's views." Id. 4092 (dissenting opinion).

77 See Appropriate Bargatning UnTT, supta note 32, at 235; Murphy, supra note 14, at 57; Recent Developments, supra note 14, at 1265 .

7850 U.S.L.W. at 4091 (Burger, C.J. \& Rehnquist, J., dissenting).

79 Id.

80 Id. 4093. 
that "the Board and the courts have acquired considerable experience in determining whether an impasse exists," ${ }^{81}$ and that the danger that either party will manipulate negotiations to create impasse is diminished by the requirement that a statemate be declared only after good faith negotiations. ${ }^{82}$

The Chief Justice also took issue with the Court's view of interim agreements, disputing the majority's assertion that employers executing such agreements had "an equivalent stake in promptly securing a reasonable final agreement." 83 The Chief Justice explained that employers who had signed interim agreements would benefit by prolonging the deadlock to increase their competitive advantage over nonsettling employers. ${ }^{84}$ Combined with the threat of a reverse whipsaw strike, this gave the union a clear bargaining advantage. ${ }^{85}$

Despite the imbalance perceived by the Chief Justice, commentators are in general agreement that the impasse doctrine creates more difficulties than it solves. ${ }^{86}$ This probably explains the trend in the courts of appeals toward rejection of the doctrine. ${ }^{87}$ Those courts, and the commentators, have rested their rejection of the doctrine on the rationale that a primary purpose of multi-employer units is to enhance the stability of collective bargaining. ${ }^{88}$ That goal is served by the Board's narrow definition of unusual circumstances justifying withdrawal.

The Board has interpreted severe economic distress stringently, requiring a real threat to an employer's economic survival to justify withdrawal after negotiations begin. Unit fragmentation, resulting

81 Id.

82 Id. (citing NLRB v. Crompton-Highland Mills, Inc., 337 U.S. 217 (1949); Cone Mills Corp. v. NLRB, 413 F.2d 445, 450 (4th Cir.), cert. denied, 396 U.S. 903 (1969)).

8350 U.S.L.W. at 4093.

$84 \mathrm{Id}$.

85 See Steel Fabricators, 582 F.2d at 147 \& n.21; Appropriate Bargaindng UNIT, supra note 32 , at 235 ("unions are able to take advantage of the weakest employers ... while the stronger bargaining concerns are prevented from disassociating themselves from the result.").

80 See supra note 14.

87 See supra note 67.

88 In Retail Assocs., 120 N.L.R.B. 388, 393 (1958), the Board noted that it limited withdrawal to satisfy the statutory requirement of stability. In Connell Typesetting Co., 212 N.L.R.B. 918, 921 (1974), the Board, discussing group bargaining, stated that it "is always concerned as to stability in the collective-bargaining relationship." See also Unelko Corp., 195 N.L.R.B. 236, 238 (1972), enforced mem., 478 F.2d 1404 (7th Cir. 1973). 
from separate permanent agrements or union consent to untimely withdrawals, permits other association members to withdraw only if the size of the unit is drastically reduced.

Impasse, by contrast, neither threatens immediate and irreparable harm nor necessarily comes about through the fault of the union. Instead, impasse may be viewed as a normal, foreseeable aspect of bargaining-a point at which economic warfare replaces regotiation. ${ }^{89}$ Allowing withdrawal at this time would alter the balance of economic forces precisely when the need for a stable, predictable unit is most acute. Moreover, to require the Board (and the parties) to determine that a statemate that is truly an impasse, rather than a hiatus, would add further uncertainty.

Recognizing the criticisms of both the impasse doctrine and of the rule adopted by the Court, Justice O'Connor wrote a separate dissent in Bonanno. She urged that the NLRB be "required to analyze, not simply label, a deadlock in negotiations . . . " 80 Thus, she would have granted employers the right to withdraw if the Board found, on a case-by-case basis, a complete breakdown of negotiations or fragmentation of the bargaining unit.

The problem with the case-by-case analysis suggested by Justice $O^{\prime}$ Connor is that it undermines the value of certainty which makes multi-employer bargaining attractive to individual employers and to unions. Employers and unions could not be certain whether a particular situation justified withdrawal; yet the price of guessing incorrectly would be unfair labor practice penalties.

In short, case-by-case analysis does not further the goals of multi-employer bargaining-flexibility, stability, and certainty. This Comment suggests that employer self-regulation best furthers these goals.

\section{A Solution: Self-Regulation}

\section{A. The Proposal}

This Comment proposes self-regulation as a replacement for the Bonanno Court's rule. Employers who desire to bargain together should be encouraged to draft a written charter governing their association.1 This charter should regulate the governance of the

89 See Note, supra note 71 , at 1317.

9050 U.S.L.W. at 4094 (O'Connor \& Powell, JJ., dissenting).

91 In Authorized Air Conditioning v. NLRB, 606 F.2d 899 (9th Cir. 1979), cert. denied, 445 U.S. 950 (1980), the Ninth Circuit stated that one of its grounds for refusing to permit employer withdrawal was that the association's by-laws forbade withdrawal at that juncture. $606 \mathrm{~F} .2 \mathrm{~d}$ at 906 . The court left open the question whether violation of the association agreement, without more, would constitute an 
association, ${ }^{92}$ specifying association rules about when withdrawal is allowed, ${ }^{93}$ whether interim or permanent separate agreements are permissible, ${ }^{94}$ and the processes for resolving internal association disputes. ${ }^{95}$

After association members sign the agreement, the union should be informed of its contents. The union then could agree to bargain according to the charter's terms, or negotiate for modifications-a course consistent with the understanding of Justice Stevens, who cast the deciding vote in Bonanno.96 Once the union consents, the

unfair labor practice. This case is significant, however, in that the court was guided by attempted self-regulation and indicated that violation of an association charter could be grounds for a $\$ 8(\mathrm{a})(5)$ violation.

92 This charter should list the association's members and the length of time the charter will be in force. It should include procedures for adding members during its tenure. With respect to governance, the charter should deal with such issues as whether decisionmaking power will be distributed equally among members, or whether larger employers will have a larger voice.

93 The association may want to retain the Board's rule allowing withdrawal in cases of severe economic distress, but could set more concrete guidelines for the severity required to permit withdrawal. Cf. Authorized Air Conditioning, 606 F.2d at 903-04 (withdrawal not permitted within four months of contract termination date).

94 For example, the association may wish to allow separate agreements concerning local matters, or interim agreements at some precisely defined point of impasse.

95 The association might agree to arbitrate all disputes, or make disagreements a political matter to be decided by a vote of the association.

9650 U.S.L.W. at $4091-92$ (concurring opinion). Justice Stevens' opinion is discussed infra at note 106.

It should be noted that negotiating over the terms of the charter should not subject the union or employers' association to certification by the NLRB as a multiemployer unit. The negotiations over charter terms raise two potential problems. First, it might be argued that the charter itself would become a bargainable subject about which the union could strike if it did not receive favorable terms. But because multi-employer bargaining is a voluntary arrangement, it is not intended that either party be permitted to use economic force to compel the other's participation. Thus, a union strike over charter terms should be an unfair labor practice. Cf. 29 U.S.C. $\$ 158$ (b)(1) (1976) (union cannot coerce employees to bargain through other than their chosen representative).

Second, it might be contended that the union-association negotiations are subject to antitrust attack under the doctrine announced in United Mine Workers v. Pennington, 381 U.S. 657 (1965). Pennington, however, only applies to conspiracies between the union and employers to impose terms on employers outside of the bargaining unit. Thus, the association may represent a group of employers, or individual employers, without antitrust consequences. It may not, however, represent a single employer-even the largest and most powerful in a multi-employer unit-if there is to be an effort to impose the agreed-upon terms on other employers within that multi-employer unit. See id. 665-67.

If an employer in the association conditioned its membership on a charter term which the union was able to remove during negotiations, antitrust liability would not arise provided that the disgruntled employer was permitted to withdraw from the association. See Bonanno, 50 U.S.L.W. at 4092 (Stevens, J., concurring). That employer would then return to individual bargaining, and could not contend that the association was "conspir[ing] to eliminate [it] from the industry. . . " Pennington, 381 U.S. at 665-66. 
agreement should be submitted to the NLRB for its approval. Provided that the multi-employer unit meets the Board's normal requirements, the Board should certify the unit. ${ }^{27}$

Board approval transforms the association into an "employer" within the meaning of the statute. ${ }^{98}$ As a statutory employer, the association gains two methods of enforcing its charter provisions. If, contrary to the terms of the charter, the union signed a separate agreement with an individual employer, the union would have refused to bargain. ${ }^{99}$ Such a refusal would be an unfair labor practice subjecting the union to a cease and desist order, nullifying the separate agreement, and binding the renegade employer to the contract negotiated through multi-employer bargaining. ${ }^{100}$

Alternatively, the association, or any of its members, could bring a breach of contract action against the offending employer in a state court. ${ }^{101}$ Rather than ordering that employer to return to the unit, the court could assess damages. ${ }^{102}$ These damages could be calculated based on the profits the settling employer gained at its colleagues' expense; but because damages would be difficult to compute, and because a suit would be disruptive to the association,

97 In order to effectuate the private ordering model this Comment advocates, the NLRB should strike down association charters accepted by unions only if the charters clearly violate public policy. Board disagreement with the association and union's view about the proper structure of multi-employer bargaining would not justify disapproving a charter.

98 See Shipowners' Ass'n, 7 N.L.R.B. 1002 (1938), appeal dismissed sub nom. AFL v. NLRB, 103 F.2d 933 (D.C. Cir. 1939), affd, 308 U.S. 401 (1940).

99 See, e.g., Teamsters Local 378, 243 N.L.R.B. 1086 (1979), application for enforcement pending, No. 79-7683 (9th Cir. argued Nov. 5, 1980) (Board held that a union signing a permanent separate agreement with an employer who, after negotiations begin, fails to obtain association permission before withdrawing violates $\$ 8(\mathrm{~b})(3)$ of the NLRA, 29 U.S.C. $\$ 159(\mathrm{~b})(3)(1976)$ ). The rationale of that case could be extended to cover an employer who violates any provision of the Association charter.

100 See Westchester County Exec. Comm., 142 N.L.R.B. 126 (1963); General Teamsters Local 324, 127 N.L.R.B. 488 (1960).

101 Whether an individual employer could bring an action to enforce the agreement, or whether the association should have the exclusive power to sue, is a subject that should be settled in the charter.

Congress has empowered courts to settle disputes in the labor contract setting. See 29 U.S.C. $\$ \$ 185(\mathrm{a})$, (b) (1976). The Supreme Court interpreted the scope of these sections in Textile Workers Union v. Lincoln Mills, 353 U.S. 448 (1957), and held that state courts could also entertain such suits in Charles Dowd Box Co. v. Courtney, 368 U.S. 502 (1962).

102 Damages should be preferred because an association charter, contemplating a continuing relationship between the parties, is not the kind of contract generally amenable to specific performance.

Because expectation damages would be extremely speculative, restitution should be the normal measure of damages. An employer resuming operations during a strike in violation of the association's rules would thus have its profits disgorged. 
the charter could provide either for mandatory arbitration or for liquidated damages.

This proposal does not necessarily afford employers and unions equal withdrawal rights. Contracting about withdrawal rights eliminates the need for Board rules, so balanced withdrawal rights for the union and employers are not required in the interest of fairness. The union can accept, reject, or attempt to modify the association agreement, thus defining withdrawal rights in advance of contract negotiations. Employers who disagree with the proposed charter can simply withdraw from the association and bargain individually. ${ }^{103}$

\section{B. Advantages of the Proposal}

Self-regulation's foremost advantage is that it permits employers and unions to formulate reasonable expectations about the structure of bargaining, and protects those expectations. As noted earlier, the Board does not now require that the intent to participate in multi-employer bargaining be evidenced by a "solemnly executed document signed and sealed in hot wax." 104 Yet a written contract has long been recognized as the best way to draw attention to the fact that parties are entering into a legally binding relationship, and to encourage them to specify clearly their mutual rights and obligations. ${ }^{105}$

\section{Employers' Advantages}

Employers join together into associations to gain bargaining leverage against the union, and competitive stability with one another. The present Board rule prevents employers from accurately predicting whether their goals are served by entering into a bargaining association, because employers may withdraw shortly before bargaining begins or reach interim agreements with the union dur-

103 Failure to draft an agreement should subject multi-employer units to the Board's rules. See supra notes 47-57 and accompanying text. Despite the shortcomings of those rules, failure to agree to bargain under a charter should be viewed as a decision by the union and employers to "consent" to the Board's approach. The current rules, however, could be made clearer. For example, the Board could take a clear stand on whether permanent, separate agreements always results in unit fragmentation. Cf. Bonanno, 50 U.S.L.W. at 4090 ("where the union . . . executes separate agreements that will survive unit negotiations, the union has so 'effectively fragmented ... the bargaining unit' as to create an 'unusual circumstance, ....") (citations omitted).

104 Joseph McDaniel, 226 N.L.R.B. at 853.

105 See Kennedy, Form and Substance in Private Law Adjudication, 89 Harv. L. Rev. 1685, 1691-92 (1976); cf. 3 J. Williston, Contracts $\$ 448$ (3d ed. 1960) (purpose of statute of frauds). 
ing negotiations. The former step disrupts other association members' plans for joint bargaining; the latter destroys the premise of mutual support. The impasse doctrine fails to alleviate these problems, allowing employers to manipulate negotiations into impasse, and then withdraw.

Self-regulation allows every employer group to protect its unique concerns. If employers desire a group in which association bargaining is limited to certain areas, they may specify in their charter that engaging in that bargaining will not make them a unit for all purposes. Employers who desire a loosely structured group can specify in their charter that withdrawal is permitted at any time (whether or not negotiations have begun).

Those employers who prefer a more structured group can design a charter limiting withdrawal even more strictly than does the Bonanno Court's rule. For example, the charter might bar withdrawal for its duration; or, less stringently, it might prohibit withdrawal from one or two months before contract negotiations are scheduled to begin. The agreement could regulate unit disruption by forbidding separate agreements of any kind-permanent or interim. To compensate for such strictness, the duration of the charter could be brief. Upon its expiration, employers dissatisfied with its terms could attempt to modify the charter or could leave the association. Thus, the parties' own decisions, not the Board's balancing of economic interests and weapons, will be honored.

\section{Advantages to Unions}

Like employers, unions would benefit from an increase in the stability and predictability of bargaining units. Unions benefit from predictability by taking advantage of economies of scale, and by engaging in more far-reaching bargaining.

The union's most important benefit is furthering its goal of security. The union would know precisely when, if ever, it could negotiate with individual employers without causing fragmentation of the unit and a consequent return to individual bargaining.

Finally, the union would benefit from the new bargaining leverage it would receive from the adoption of self-regulation. The union could consent to charter terms important to the association in exchange for association concessions on wages or working conditions.

\section{Benefits From Enhanced Stability}

The reduced temptation for individual employers to withdraw resulting from self-regulation would benefit the association, the 
union, and the public. The instability stemming from changing economic conditions would be lessened by specifying the length of the agreement, rather than letting it exist indefinitely. Pressures for withdrawal based on dissension between employers over bargaining strategy would be dissipated by an agreement about the process for resolving disputes.

The pressures for withdrawal that result from the changing composition of multi-employer bargaining units would also be minimized through self-regulation. If the association agreement prevented the union from negotiating separate agreements, a major source of intra-association frustration and resentment would be avoided. Thus, employers can-by a term of the charter-organize themselves to insure that "they will hang together for the long pull." 106

The public would also benefit from the labor peace derived from increased stability and more informed long-range planning by unions and employers. Yet the public would be protected from excessive collusion between employers by the antitrust laws, and from agreements between unions and employers violative of public policy by the requirement of NLRB ratification.

\section{Conclusion}

Unions and employers agree to bargain on an association-wide basis because they expect stability in the unit and flexibility in negotiations. If those expectations are frustrated, pressures for withdrawal build. The Board's rule, because it fails to maintain flexibility in regulating withdrawal, frustrates expectations and leads to instability in bargaining units. Yet the response to the Board's rule,

106 S. GarReTt \& L. TRIPP, supta note 19, at 60.

Justice Stevens, who cast the deciding vote in Bonanno, endorsed a model closely approaching this Comment's suggestion. 50 U.S.L.W. at 4091-92 (concurring opinion). Justice Stevens emphasized the voluntary nature of multi-employer bargaining and the need for association members to indicate an "unequivocal intention to be bound in collective bargaining by group rather than individual action . . . "Id. 4091 (quoting Weyerhaeuser Co., 166 N.L.R.B. 299, 299 (1967), enforced, 398 F.2d 770 (D.C. Cir. 1968)). Thus, Justice Stevens stated that: "Absent such an unequivocal commitment to be bound by group action, any employer is free to withdraw from group negotiation at any time, or simply to reject the terms of the final group contract." Id. He read the Court's opinion to "not preclude an employer from explicitly conditioning its participation in group bargaining on any special terms of its own design." Id.

Justice Stevens then gave the example of an association refusing to participate in multi-employer bargaining unless the union accepted a term permitting withdrawal at impasse, and discussed the consequences of the union's refusal to accept that term. His view, like that suggested by this Comment, is that employers and unions should be permitted to tailor the structure and terms of multi-employer bargaining to their precise needs. 
the impasse doctrine, likewise contributes to instability by allowing employers to manipulate negotiating stalemates and thus to destroy the unit.

Self-regulation provides a means of vindicating the goals of flexibility, stability, and certainty for both employers and unions. Self-regulation permits each party to arrange a framework for negotiations tailored to its particular goals. Unexpected disintegrations are minimized, so that the association and the union can concentrate on the success of the bargaining process instead of the possible breakdown of the unit. Given the two means of enforcing the association charter, employers will be reluctant to take steps that might subject them to liability. Thus, emphasis will be on bargaining and not on withdrawal. 